\title{
ANALISIS DAMPAK PENGELUARAN PEMERINTAH DI BIDANG PENDIDIKAN TERHADAP PDB PER KAPITA: SPENDING MORE OR SPENDING BETTER
}

\author{
Achmad Rifa'i* \\ Kedeputian Bidang Ekonomi, Kementerian Perencanaan Pembangunan Nasional/ Bappenas, Jakarta \\ achmadrifai186@gmail.com \\ Ganiko Moddilani \\ Kedeputian Bidang Perniagaan dan Industri, Kementerian Koordinator Bidang Perekonomian, Jakarta \\ ganicko@gmail.com
}

*Alamat Korespondensi: achmadrifai186@gmail.com

\begin{abstract}
Government spending is the first way to create quality human resources through budget allocation commitments in the education sector. In turn, a labor market filled with quality human resources will encourage welfare and productivity and it will impact the national economy. This study aims to analyze the relationship of government spending in education to the aggregate welfare proxied using GDP per capita. This study used time-series data 1980-2018 from World Development Indicators (WDI) World Bank. Vector Error Correction Model (VECM) is employed to analyze the government spending in the education sector to the welfare. Empirically, the findings of this study reveal that government spending in the education sector affects aggregate welfare with a little magnitude. The issue of equity and disparity in fiscal capacity among regions is the main matter. On the other side, Geographic, social, cultural, and population conditions are challenges that must be solved by the government.
\end{abstract}

KEYWORDS: Education, Government Expenditure, VECM, Welfare

\begin{abstract}
ABSTRAK
Pengeluaran pemerintah menjadi jalan pertama dalam menciptakan sumber daya manusia (SDM) yang berkualitas melalui komitmen alokasi anggaran di bidang pendidikan. Pada gilirannya, pasar tenaga yang diisi SDM berkualitas akan mendorong kesejahteraan dan produktivtas secara agregat yang kemudian akan berdampak terhadap perekonomian nasional. Penelitian ini bertujuan untuk menganalisa hubungan pengeluaran pemerintah di bidang pendidikan terhadap tingkat kesejahteraan yang diproksikan menggunakan PDB per kapita. Penelitian ini menggunakan data deret waktu 1984-2018 bersumber dari Indikator Perkembangan Dunia (WDI) Bank Dunia. Vector Error Correction Model (VECM) digunakan untuk menganalisa kontribusi pengeluaran pemerintah di bidang pendidikan terhadap tingkat kesejateraan. Secara empiris, temuan dari penelitian ini mengungkapkan bahwa pengeluaran pemerintah di bidang pendidikan berpengaruh terhadap tingkat kesejahteraan namun dengan kontribusi yang belum optimal. Isu pemerataan dan disparitas kapasitas fiskal antar wilayah menjadi penyebab utama. Disisi lain, kondisi geografi, sosial, budaya, dan populasi yang beragam menjadi tantangan yang harus diselesaikan pemerintah.
\end{abstract}

KATA KUNCI: Kesejahteraan, Pendidikan, Pengeluaran Pemerintah, VECM

KLASIFIKASI JEL: H52, I25, I22

CARA MENGUTIP: Rifa'i, A., \& Moddilani, G. (2021). Pengeluaran pemerintah di bidang pendidikan terhadap pdb per kapita: spending more or spending better. Indonesian Treasury Review: Jurnal Perbendaharaan, Keuangan Negara, dan Kebijakan Publik, 6(3), 211-226. 


\section{PENDAHULUAN}

Pendidikan merupakan salah satu variabel penting dalam perekonomian. Pendidikan yang berkualitas menciptakan sumber daya manusia (SDM) yang berkompeten. SDM tersebut kemudian akan masuk ke dalam pasar tenaga kerja dan menjadi bagian dari struktur perekonomian yang mendorong produktivitas semakin tinggi. Cobb \& Douglas (1928) menggambarkan pentingnya peran tenaga kerja dalam sebuah fungsi produksi. Dalam hal ini, tenaga kerja yang berkompeten dan berkualitas dihasilkan dari sebuah sistem pendidikan yang sejalan secara paralel dengan kebutuhan pasar dan perkembangan zaman.

Sistem pendidikan diciptakan dari sebuah visi pembangunan yang jauh melihat ke depan. Karena pendidikan merupakan investasi peradaban, dimana dampaknya tidak terasa secara instan, namun diperlukan waktu yang cukup lama untuk melihat hasil dari investasi tersebut. Melihat durasi waktu yang cukup lama untuk merasakan dampak dari investasi pendidikan, aspek yang sangat krusial dari sebuah penyelenggaran pendidikan adalah ketersediaan anggaran. Ketersediaan anggaran sangat penting dalam rangka memastikan kesinambungan alokasi anggaran di bidang pendidikan untuk menjamin SDM yang mampu berkreativitas di tengah tuntutan zaman yang semakin tinggi.

Pemerintah selaku penyelenggara negara diamanatkan dalam pasal 31 Ayat 4 UndangUndang Dasar (UUD) 1945 bahwa alokasi anggaran untuk bidang pendidikan minimal 20 persen, baik melalui intervensi dari Anggaran Pendapatan dan Belanja Negara (APBN) atau Angaran Pendapatan dan Belanja Daerah (APBD). Meskipun alokasi anggaran tidak secara langsung mempengaruhi kualitas tenaga kerja, peran anggaran sangat penting karena mandatory spending sebesar 20 persen dari APBN merupakan awal dari proses penyelenggaraan sistem pendidikan.

\section{PENERAPAN DALAM PRAKTIK}

1. Kapasitas fiskal yang tidak merata di setiap daerah menyebabkan kontribusi pengeluaran pemerintah di bidang pendidikan belum optimal mendorong kesejahteraan.

2. Pemerintah pusat perlu memperkuat peran pengawasan terhadap pengeluaran di bidang pedidikan dan menerapkan reward and punishment bagi daerah.

3. Kesejahteraan pada dasarnya terletak pada pembangunan manusia sehingga pemerintah perlu merubah paradigma dari meningkatkan kuantitas menjadi mendorong kualitas pengeluaran pendidikan.

Selanjutnya, pengalokasian anggaran bidang pendidikan sebesar 20 persen dari APBN merupakan salah satu kebijakan pengeluaran pemerintah. Pentingnya pengeluaran yang dilakukan pemerintah merupakan sebuah cara untuk menciptakan kesetaraan yang lebih besar, salah satunya melalui alokasi anggaran pendidikan (Hall, 2014). Pengeluaran pemerintah untuk pelayanan publik memiliki dua tujuan dasar, yaitu efisiensi dan pemerataan (Castro-Leal et al., 2000). Efisiensi dapat dicapai ketika belanja publik menghasilkan manfaat eksternal atau mampu memperbaiki kegagalan pasar, termasuk peran pemerintah dalam pengadaan publik. Sementara itu, pemerataan dimaksudkan untuk meningkatkan distribusi kesejahteraan ekonomi atau distribusi pendapatan yang lebih adil. Lebih lanjut, bidang pendidikan merupakan salah satu pengeluaran pemerintah yang mendapat perhatian khusus.

Secara umum, geografi Indonesia yang berbentuk kepulauan dengan jumlah 34 provinsi dan lebih dari 500 kabupaten/kota serta jumlah penduduk terbesar keempat di dunia menciptakan disparitas pembangunan. Lebih jauh, disparitas tersebut terlihat dari share Produk Domestik Regional Bruto (PDRB) terhadap Produk Domestik Bruto (PDB) yang didominasi oleh daerah yang

\section{Grafik 1. Share Wilayah terhadap PDB}

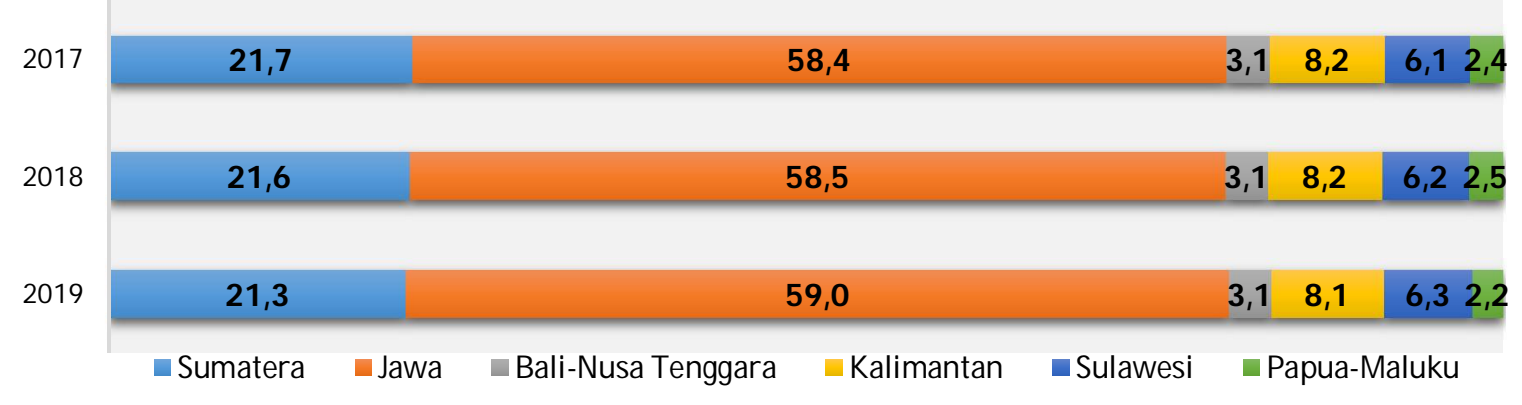


berasal dari wilayah barat, terutama di Pulau Jawa. Sementara itu, daerah timur Indonesia berkontribusi sangat minim. Disparitas tersebut terjadi karena sistem pendidikan Indonesia sangat besar dan beragam. Lebih dari 60 juta siswa dan hampir 4 juta guru pada sekitar 340.000 lembaga pendidikan merupakan sistem pendidikan terbesar ke-tiga di kawasan Asia dan terbesar ke-empat di dunia (Ozawa \& Lee, 2011)(OECD/ ADB, 2015). Oleh karena itu, pemerataan di bidang pendidikan menjadi sebuah tantangan besar di Indonesia.

Grafik 1 menunjukkan bahwa share PDRB di Pulau Jawa terhadap PDB Nasional semakin mendominasi dalam tiga tahun terakhir. Tingginya share PDRB terhadap PDB di Pulau Jawa mengindikasikan perekonomian yang masih bertumpu pada satu kawasan. Perekonomian yang kuat di wilayah Jawa, salah satunya didorong oleh melimpahnya tenaga kerja. Fakta ini sejalan dengan jumlah penduduk di wilayah Jawa yang padat. Selain jumlah penduduk yang padat, kualitas pendidikan di wilayah Jawa cenderung lebih baik dibandingkan dengan wilayah lain. Lebih lanjut, kapasitas fiskal pemerintah wilayah Jawa juga cenderung lebih kuat dibandingkan wilayah lain, karena didorong sektor industri yang kuat di wilayah tersebut, sehingga meningkatkan penghasilan baik pada sisi permintaan dan penawaran yang mana semuanya kemudian saling berinteraksi dan berimplikasi pada penerimaan pajak yang lebih tinggi.

Penerimaan pajak yang terjaga akan sangat mempengaruhi kesinambungan pembiayaan pembangunan termasuk pada bidang pendidikan. Lebih jauh, kesinambungan tersebut tercermin dari upaya pemerintah untuk memberikan perhatian yang besar terhadap pendidikan.

Negara yang memiliki kesejahteraan yang baik cenderung memiliki tingkat pendidikan yang tinggi dan merata (Hawkes \& Ugur, 2012). Secara makro, kesejahteraan suatu daerah bisa diukur dengan tingkat PDRB per kapita. Semakin tinggi PDRB per kapita maka diasumsikan tingkat pendapatan penduduk semakin tinggi dan sebaliknya. Meskipun indikator ini tidak secara mutlak sebagai cerminan tingkat kesejahteraan, paling tidak terlihat kapasitas suatu daerah dalam mengelola ekonomi dan penduduknya. Namun demikian, tantangan utama dalam pembangunan di Indonesia sebenarnya masih berfokus pada indikator pemerataan.

Berdasarkan Grafik 2, DKI Jakarta menjadi daerah yang memiliki PDRB per kapita tertinggi mencapai Rp165 juta pada tahun 2018, diikuti oleh Kalimantan Timur, Kepulauan Riau dan seterusnya. Beberapa daerah yang memiliki PDRB per kapita tinggi lebih dikarenakan jumlah penduduknya yang sedikit, denga kapasitas ekonominya bertumbuh cukup tinggi. Tentu kondisi tersebut sifatnya kontradiktif dengan Grafik 1 sebelumnya, dimana daerah di luar wilayah Jawa memiliki share PDRB yang rendah terhadap PDB. Dengan demikian, dapat dikatakan bahwa SDM daerah belum mampu secara optimal mengelola potensi kapasitas ekonominya. Padahal, potensi ekonomi yang tinggi hanya akan menjadi indikator semu apabila tidak dibarengi dengan SDMyang baik.

Kualitas SDM yang tidak merata didorong oleh ketidakmerataan kepasitas fikal setiap daerah yang berimplikasi pada banyak sektor, salah satunya kemampuan dalam menyediakan fasilitas pendidikan. Padahal, fasilitas pendidikan yang baik diduga akan mendorong lahirnya SDM terampil yang berpotensi mengisi pasar tenaga kerja. Selain itu, fasilitas pendidikan yang baik juga mendorong implemetasi sistem pendidikan yang memiliki visi jauh ke depan menjadi lebih baik. Oleh karena itu, meskipun dalam penyelenggaraan pendidikan membutuhkan alokasi yang besar, ini semua merupakan investasi peradaban yang timbal balik hasilnya akan terus berkesinambungan (Ifa \& Guetat, 2018).

Dengan demikian, sangat penting untuk dianalisa lebih mendalam peran pendidikan dalam menciptakan SDM terampil dan berkompeten dalam rangka mengelola potensi ekonomi. Peran pendidikan tersebut tercermin dari keberpihakan pemerintah melalui alokasi anggaran di bidang pendidikan yang berkesinambungan. Sehingga diharapkan melalui alokasi anggaran tersebut akan mendorong tingkat kesejahteraan yang adil dan merata secara nyata melalui sistem pendidikan yang memiliki visi jauh ke depan.

\section{STUDI LITERATUR}

Pengeluaran publik sering dikategorikan ke dalam pengeluaran yang produktif dan tidak produktif. Pengkategorian ini menyiratkan bahwa pengeluaran produktif memiliki pengaruh positif secara langsung pada pertumbuhan ekonomi, sementara pengeluaran tidak produktif memiliki efek tidak langsung atau tidak berpengaruh. Analisis kuantitatif mungkin belum mampu untuk menangkap pengembalian atas pengeluaran tersebut dalam jangka pendek (Maitra \& Mukhopadhyay, 2012). Secara umum, pengeluaran untuk pendidikan dianggap sebagai pengeluaran produktif dengan peran komprehensif dalam perekonomian. Pengembalian dari pengeluaran pendidikan sering diperhitungkan dalam hal sebuah 


\section{Grafik 2. PDRB Per Kapita Indonesia 2018 (juta Rp)}

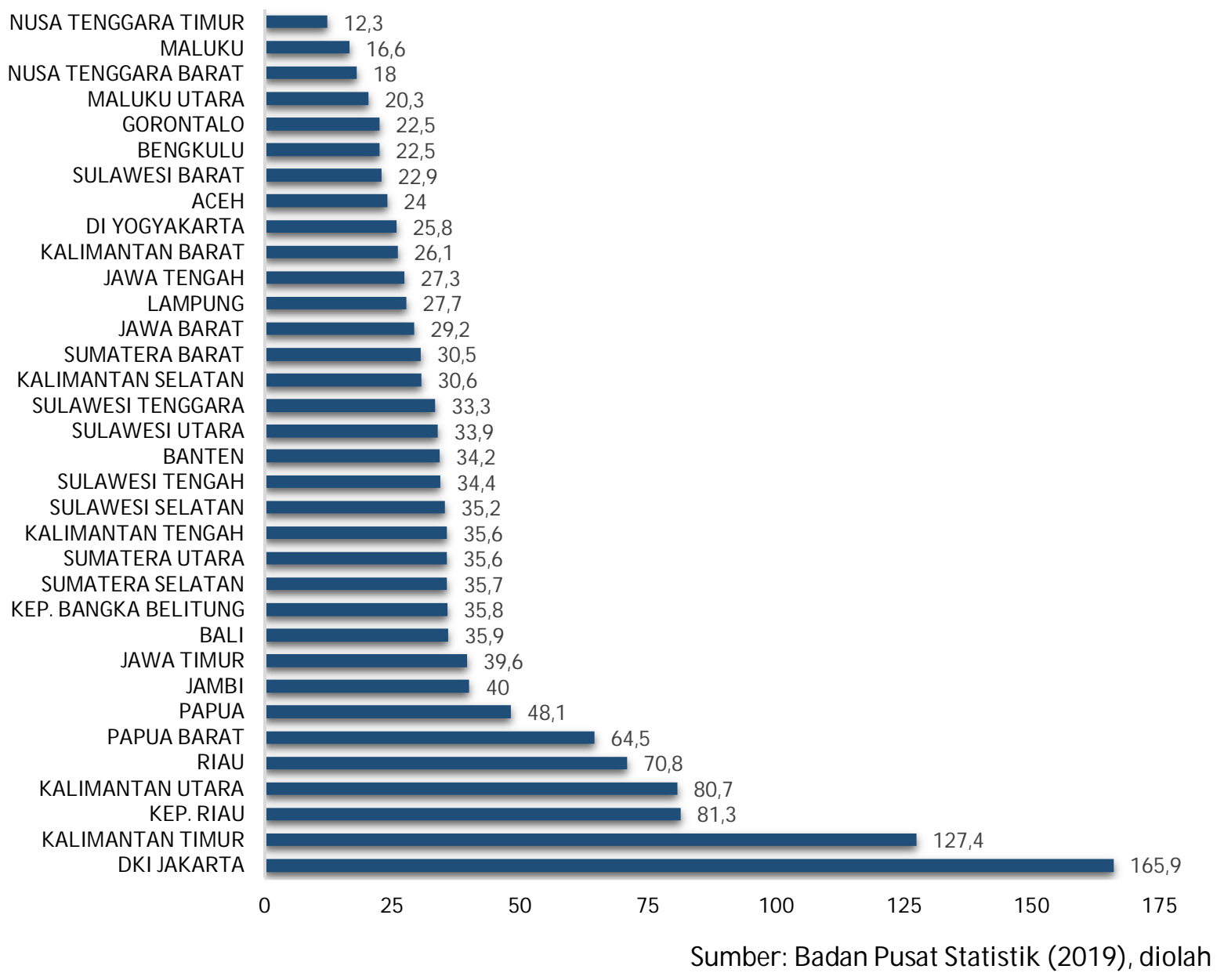

kemajuan, misalnya seperti pendapatan individu yang semakin meningkat.

Pengeluaran global untuk bidang pendidikan telah meningkat secara signifikan selama dua dekade terakhir, meskipun proporsi pengeluaran dari PDB relatif tidak berubah yaitu sekitar 4,5 persen. Namun demikian, tren global menutupi perbedaan besar lintas wilayah dan kelompok pendapatan negara. Sebagai contoh, negara-negara berpenghasilan rendah mencatat peningkatan terbesar dalam hal proporsi PDB yang dihabiskan untuk pendidikan, tetapi jumlah absolut yang mereka berikan untuk pendidikan tetap rendah dibandingkan dengan negara-negara lain (Alsamarrai et al., 2019).

Sementara itu, terus meningkatnya biaya pendidikan semakin menunjukkan bahwa sistem pendidikan perlu dilakukan secara lebih efisien untuk mendorong pertumbuhan ekonomi jangka panjang (Nose, 2015). Untuk mengatasi isu tersebut, para pembuat kebijakan perlu memahami faktor-faktor penentu dari kenaikan biaya pendidikan di masa lalu. Biaya pendidikan yang muncul merupakan investasi yang memiliki efek positif pada tenaga kerja dan ekonomi. Selain itu, negara-negara yang memiliki cadangan SDM yang lebih besar dan berinvestasi lebih banyak untuk pendidikan atau penelitian dan pengembangan menikmati tingkat pertumbuhan ekonomi yang lebih cepat (Amaghionyeodiwe, 2015).

Investasi pada bidang pendidikan kemudian tercermin dari alokasi anggaran yang berkesinambungan pada bidang Pendidikan. Hal ini membantu mempertahankan tenaga kerja yang produktif dengan keterampilan sesuai permintaan pasar dan melengkapi pertumbuhan teknologi. Lebih lanjut, terdapat peningkatan tambahan dalam produktivitas pasar yang disebabkan oleh SDMyang diperoleh dari sekolah. Selanjutnya, eksternalitas positif yang muncul dari pendidikan dapat memacu pertumbuhan ekonomi melalui faktor-faktor endogen lainnya seperti inovasi teknologi (Frank, 2018).

Ekinci et al. (2017) menjelaskan bahwa tenaga kerja dalam suatu perekonomian akan tumbuh seiring dengan meningkatnya populasi dan partisipasi angkatan kerja di bagian tertentu dari peningkatan populasi ini. Kualifikasi atau kualitas tenaga kerja, khususnya pendidikan sekolah dan tempat kerja, juga tumbuh seiring dengan 
pertumbuhan modal manusia di negara tersebut. Modal manusia dapat dinyatakan sebagai jumlah dari pengetahuan dan keterampilan yang terkandung dalam angkatan kerja.

Secara umum, tenaga kerja yang berpendidikan lebih produktif dan juga dapat meningkatkan produktivitas rekan kerjanya. Lebih lanjut, cadangan modal manusia yang lebih tinggi memfasilitasi investasi dalam modal fisik dan meningkatkan pengembangan dan difusi teknologi baru, yang pada gilirannya mempengaruhi output per tenaga kerja. Berbagai manfaat tidak langsung dari pendidikan juga cenderung memiliki konsekuensi ekonomi positif. Sebagai contoh, pendidikan yang lebih tinggi dikaitkan dengan status kesehatan yang superior dan peningkatan dalam beberapa aspek kohesi sosial dan partisipasi politik (OECD, 2006).

Dengan demikian, dapat dikatakan bahwa alokasi anggaran pendidikan yang kemudian menjadi sebuah variabel pengeluaran publik pemerintah di bidang pendidikan memiliki dampak yang beragam terhadap ekonomi secara makro. Meskipun demikian, dampak secara mikro terutama pada kesejahteraan masih belum terlalu banyak dibahas. Dao (2012) menemukan bahwa pentingnya peran pengeluaran pemerintah di bidang pendidikan untuk merangsang pertumbuhan ekonomi. Selain itu, negara-negara berkembang yang kebijakan pemerintahnya terus meningkatkan pengeluaran per kapita untuk pendidikan, pendapatannya relatif tumbuh lebih cepat.

Pendidikan juga sangat berperan dalam meningkatkan modal sosial dan kesejahteraan sosial (Guisan, 2006). Secara meyakinkan, alokasi belanja untuk pendidikan memiliki efek yang signifikan untuk mengurangi tingkat kemiskinan di daerah pedesaan, sementara penurunan tingkat kemiskinan di perkotaan cenderung lebih dipengaruhi oleh pengeluaran untuk kesehatan. Oleh karena itu, untuk mengurangi kemiskinan secara lebih efektif, akan lebih baik bagi pemerintah untuk memfokuskan program pengurangan kemiskinannya pada investasi di bidang pendidikan. Pada gilirannya, tingkat kemiskinan yang menurun akan mendorong tingkat kesejahteraan secara umum (Taruno, 2019).

Selanjutnya, Appiah (2017) menemukan bahwa ekspansi belanja pendidikan memiliki efek positif terhadap PDB per kapita. Lebih lanjut, tidak ditemukan perbedaan signifikan dalam dampak pengeluaran pendidikan terhadap PDB per kapita di negara-negara berkembang dan negara-negara SubSaharan Africa (SSA). Namun, besarnya dampak lebih tinggi di negara-negara berkembang daripada negara-negara SSA. Kondisi ini menunjukkan bahwa meskipun pertumbuhan ekspor tahunan negaranegara SSA relatif lebih tinggi daripada negaranegara berkembang lainnya, negara-negara SSA tidak memiliki SDM berkompeten dan terampil yang mampu menambah nilai pada produk mereka. Dengan demikian, penting bagi SSA untuk meningkatkan tingkat SDM yang mampu membuat dampak signifikan pada PDB per kapita.

Shafuda \& De (2020) juga menemukan hasil yang serupa, dimana analisis mereka menunjukkan bahwa terdapat hubungan jangka panjang antara pengeluaran pemerintah untuk pendidikan dan indikator pendidikan terutama melalui angka partisipasi murni netto serta angka partisipasi tersier bruto. Hasil lebih lanjut menunjukkan bahwa ada hubungan jangka panjang antara pengeluaran pemerintah untuk pendidikan, kesehatan, dan PDB per kapita. Saraswati (2013) juga mengungkapkan hal yang serupa yaitu dampak belanja pendidikan mempercepat pertumbuhan ekonomi, meningkatkan kualitas angkatan kerja, dan kesejahteraan rakyat miskin.

Penelitian Kouton (2018) menemukan hal yang unik dimana tidak terdapat hubungan jangka pendek dari pengeluaran pendidikan pemerintah pada pertumbuhan ekonomi di Pantai Gading. Namun demikian, terdapat hubungan jangka panjang antar kedua variabel. Hal yang mengejutkan dari penelitian tersebut adalah bahwa pengaruh pengeluaran pendidikan pemerintah terhadap pertumbuhan ekonomi adalah negatif dalam jangka panjang. Menurut Kouton (2018), rendahnya tingkat pengeluaran untuk pendidikan pemerintah dan ketidakefisienan sistem penganggaran diduga menjadi penyebab hubungan negatif tersebut.

Bagaimanapun juga, hasil penelitian dari berbagai negara menemukan hal yang berbedabeda. Secara umum, pengeluaran pemerintah di bidang pendidikan menunjukkan dampak yang baik terhadap perekonomian dan kesejahteraan. Namun juga, terdapat isu rendahnya alokasi pendidikan yang menyebabkan secara empiris terjadi hubungan negatif. Berdasarkan hal tersebut, penting bagi pemerintah untuk menyusun alokasi anggaran yang efisien dan tepat sasaran sehingga dampak yang diharapkan dari pengeluaran pemerintah terutama bidang pendidikan dapat tercapai dan berpengaruh positif terhadap kesejateraan.

\section{METODOLOGI PENELITIAN}

Penelitian ini menggunakan model analisa time series dengan data sekunder yang bersumber dari World Bank tahun 1984-2018. Variabel dependen dalam penelitian ini adalah PDB per kapita (GDP_Percapita), sedangkan variabel 
independennya yaitu tingkat inflasi dengan menggunakan proksi consumer price index (CPI), pengeluaran pemerintah bidang pendidikan (EDUC), tingkat partisipasi sekolah primer (PRIMER), tingkat partisipasi sekolah sekunder (SEKUNDER), dan tingkat partisipasi sekolah tersier (TERSIER). Adapun model umum ekonometrika pada penelitian ini adalah sebagai berikut.

GDP_Percapitat $=\alpha_{1}+\beta_{1} \mathrm{CPI}_{\mathrm{t}}+\beta_{2}$ EduCt $_{t}+\beta_{3}$ Primer $_{\mathrm{t}}+$ $\beta_{4}$ Sekunder $_{t}+\beta_{5}$ Tersier $_{t}+e_{t}$

Selanjutnya, data time series berpotensi menghasilkan spurious regression. Untuk mengatasi spurious regression, uji akar unit Augmented DickeyFuller (ADF) dan Vector Auto Regressive (VAR) serta kointegrasi digunakan dalam analisis penelitian ini. Model ini bergantung pada hubungan yang saling terintegrasi antar variabel, Error Correction Model (ECM) digunakan untuk menganalisa hubungan antara pengeluaran pemerintah untuk pendidikan dan PDB per kapita sebagai indikator pertumbuhan ekonomi (Liu et al., 2008).

Pengujian stasioneritas variabel dilakukan dengan menggunakan uji unit root ADF (Dickey \& Fuller, 1979) dan kemudian uji ko-integrasi antara variabel dilakukan dengan menggunakan uji Johansen (Johansen, 1988). Untuk tes ADF menggunakan persamaan berikut:

$\Delta \operatorname{Ln} X_{t}=a+b \operatorname{Ln} X_{t-1}+\sum c_{j} \Delta \operatorname{Ln} X_{t-j}+e_{t}$

dimana Xt menunjukkan masing-masing variabel. $\Delta$ adalah operator difference, sementara a, b, dan c adalah parameter yang harus diestimasi. Jika statistik ADF yang dihitung kurang dari (lebih tinggi dari nilai absolut) nilai kritis, maka hipotesis nol (H0) dari unit root ditolak dan series dianggap stasioner atau terintegrasi pada derajat nol, yaitu I (0).

Menurut Sims (1980), jika ada simultanitas antar variabel, model Vector Autoregressive (VAR) harus digunakan. Model VAR menunjukkan bahwa jika tidak banyak pengetahuan tentang kekuatan yang mempengaruhi suatu variabel, maka perlakukan variabel-variabel tersebut secara simetris. Hal Ini ditunjukkan oleh sistem persamaan berikut:

$\operatorname{Ln} Y_{t}=\beta_{10}+\beta_{11} \operatorname{Ln} Y_{t-1}+\beta_{12} \operatorname{Ln} X_{t-1}+U_{\text {Lnyt }}$

$\operatorname{Ln} Y_{t}=\beta_{20}+\beta_{21} \operatorname{Ln} Y_{t-1}+\beta_{22} \operatorname{Ln} X_{t-1}+U_{L n y t}$

dimana $U_{y t}$ dan $U_{x t}$ berkorelasi dengan white noise dan koefisien $\beta_{i j}$. Persamaan (2) dan (3) dalam bentuk tereduksi. $Y_{t}$ dan $X_{t}$ adalah variabel yang di uji dalam hubungan jangka pendek. $Y_{t-1}$ dan $X_{t-1}$ adalah nilai lag dari $Y_{t}$ dan $X_{t}, \mathrm{t}=1,2,3 \ldots$, T. $\beta_{s}$ merupakan parameter yang diestimasi.

\section{Johansen Co-Integration Test dan Error- Correction Model}

Konsep kointegrasi pertama kali diperkenalkan oleh Granger (1981) dan dielaborasi lebih lanjut oleh Engle \& Granger (1987) dan Johansen (1991). Pengujian untuk kointegrasi adalah langkah yang perlu untuk meneliti apakah ada hubungan jangka panjang yang bermakna secara empiris antara variabel.

Jika $Y_{t}$ dan $X_{t}$ berkointegrasi, artinya $\hat{\mu}_{t} \sim I(0)$ di mana û menunjukkan residu. Dengan demikian, kita dapat menyatakan hubungan antara $Y_{t}$ (variabel dependennya yaitu PDB per kapita.) dengan $X_{t}$ (pengeluaran pemerintah untuk pendidikan, CPI, tingkat partisipasi sekolah primer, sekunder, dan tersier) dengan spesifikasi ErrorCorrection Model (ECM) sebagai berikut:

$\Delta \operatorname{Ln} X_{t}=a+b_{1} \Delta \operatorname{Ln} X_{t-1}-\pi \hat{\mu}_{t}+e_{t}$

ECM memungkinkan untuk dimasukkan informasi jangka pendek dan panjang. Dalam model ini, $\mathrm{b}_{1}$ adalah dampak secara multiplier, efek penyesuaian jangka pendek, yang mengukur dampak langsung perubahan $X_{t}$ terhadap perubahan $Y_{t}$, sementara $\pi$ adalah efek umpan balik, atau efek penyesuaian. Ini menunjukkan berapa banyak disekuilibrium diperbaiki di setiap waktu.

Dalam error correction model, istilah error correction yang relevan (ECt-1) dimasukkan dalam prosedur kausalitas Granger setelah semua variabel dibuat stasioner dengan cara differencing, hasilnya Persamaan 6 dan 7:

$$
\begin{aligned}
\Delta L n Y_{t}= & \alpha_{1}+\sum_{i=1}^{n} \beta_{i} \Delta L n Y_{t-i}+\sum_{j=1}^{m} \gamma j \Delta L n X_{t-j}- \\
& \emptyset_{2} E C_{t-i}+\varepsilon_{1 t}
\end{aligned}
$$

$$
\begin{aligned}
\Delta \operatorname{LnX} X_{t}= & \alpha_{2}+\sum_{i=1}^{n} \sigma_{i} \Delta \operatorname{LnX} X_{t-i}+\sum_{j=1}^{m} \partial j \Delta \operatorname{Ln} Y_{t-j}- \\
& \emptyset_{2} E C_{t-i}+\varepsilon_{2 t}
\end{aligned}
$$

Dimana $\Delta$ adalah operator first difference, $\mathrm{t}$ adalah waktu, $\sigma_{i}, \beta_{i}, \gamma_{i}, \sigma_{i}$, dan $\delta_{i}$ merupakan koefisien yang berhubungan dengan VAR, subskrip menunjukkan urutan persamaan itu. $\mathrm{Rt}=\left(\varepsilon_{1 \mathrm{t}}, \varepsilon_{2 \mathrm{t}}\right)^{\prime}$ adalah vektor gangguan yang tidak berkorelasi, sedangkan $\alpha_{1}$ dan $\alpha_{2}$ adalah konstanta. $\mathrm{EC}_{\mathrm{t}-1}$ adalah istilah error correction. Variabel independen dikatakan menyebabkan variabel dependen berhubungan signifikan jika error correction (ECt-1) signifikan (Ø atau $\varnothing_{2}$ adalah nol) atau koefisien dari variabel independen (penjumlahan dari $\gamma j$ atau penjumlahan dari $\partial j$ adalah signifikan). Namun, jika seri tidak 
terkointegrasi, uji Granger dilakukan tanpa syarat error correction.

\section{HASIL DAN PEMBAHASAN}

Tabel 1 menunjukkan hasil uji stasioneritas ADF untuk variabel yang diubah log pada derajat level, dan first difference. Hasilnya gagal menolak hipotesis nol, non stasioneritas (unit root) pada level termasuk intersep, untuk semua variabel. Namun, hipotesis non-stasioneritas ditolak pada tingkat first difference untuk semua variabel.

Tabel 1. Hasil Uji Stasioneritas ADF

\begin{tabular}{ccc}
\hline Variabel & $\begin{array}{c}\text { Level } \\
\text { Prob. }\end{array}$ & $\begin{array}{c}\text { 1st Diff } \\
\text { Prob. }\end{array}$ \\
\hline LEDUC & 0.9883 & 0.0023 \\
LCPI & 0.6995 & 0.0010 \\
LGDP PERCAPITA & 0.9579 & 0.0019 \\
LPRIMER & 0.3188 & 0.0000 \\
LSEKUNDER & 0.5691 & 0.0037 \\
LTERSIER & 0.7426 & 0.0000 \\
\hline
\end{tabular}

\section{Penentuan Lag Optimal}

Seperti disebutkan sebelumnya, uji kointegrasi Johansen digunakan untuk mengukur keberadaan hubungan jangka panjang antara variabel. Tetapi pendekatan koordinasi Johansen sensitif terhadap panjang lag. Jadi, panjang lag ditentukan secara sistematis. Ada beberapa kriteria yang digunakan untuk menentukan pemilihan panjang lag. Kriteria tersebut yaitu Akaike Information Criterion (AIC), Schwarz Information Criterion (SC), dan HannanQuinn Information Criterion (HQ). Menurut standar AIC, SC, dan HQ, kita harus memilih model dengan nilai terendah. Semakin rendah nilainya, semakin baik modelnya. Lag optimum dengan criteria AIC dan HQ ada pada lag ke 1 (Tabel 2).

\section{Uji Kausalitas Granger}

Tabel 3 menunjukkan hasil uji Kausalitas Granger. Uji ini digunakan untuk melihat arah hubungan di antara variabel lnGDP_Percapita, lnEDUC, InPRIMER, lnSEKUNDER, dan InTERSIER. Ada tidaknya hubungan dilihat dari nilai probabilitas dari masing-masing uji kausalitas yang kemudian dibandingkan dengan alpha 0,05 maupun alpha 0,1 .

Uji kausalitas Granger pertama antara variabel pengeluaran pemerintah di bidang pendidikan dengan inflasi menunjukkan bahwa pengeluaran pemerintah di bidang pendidikan secara Granger menyebabkan inflasi dan inflasi secara Granger juga menyebabkan pengeluaran pemerintah di bidang pendidikan. Dengan demikian terjadi kausalitas antara pengeluaran bidang pendidikan dan inflasi.

Uji kausalitas Granger kedua antara PDB per kapita dengan inflasi menunjukkan bahwa PDB per kapita tidak secara Granger menyebabkan inflasi, sedangkan inflasi secara Granger menyebabkan PDB per kapita. Dengan demikian tidak terjadi kausalitas antara PDB per kapita dengan inflasi.

Uji kausalitas Granger kedua antara PDB per kapita dengan pengeluaran pemerintah di bidang pendidikan menunjukkan bahwa PDB per kapita secara Granger menyebabkan pengeluaran pemerintah di bidang pendidikan, dan pengeluaran pemerintah di bidang pendidikan secara Granger menyebabkan PDB per kapita. Dengan demikian terjadi kausalitas antara PDB per kapita dengan pengeluaran pemerintah di bidang pendidikan.

Sementara itu, untuk uji kausalitas Granger variabel yang lain seperti yang terlihat dalam tabel tidak menunjukkan kausalitas dua arah. Variabel yang memiliki kausalitas dua arah hanya pengeluaran pemerintah di bidang pendidikan dengan inflasi dan PDB per kapita dengan pengeluaran pemerintah pada bidang pendidikan.

\section{Uji Kointegrasi}

Uji kointegrasi dapat dilakukan dengan menggunakan metode Johansen. Kesimpulan yang diambil adalah berdasarkan atas perbandingan antara trace statistic dengan nilai kritis pada alpha

Tabel 2. Hasil Penentuan Lag Optimal

\begin{tabular}{cccllcl}
\hline Lag & \multicolumn{1}{c}{ LogL } & LR & \multicolumn{1}{c}{ FPE } & AIC & SC & HQ \\
\hline 0 & 353.9127 & NA & $1.45 \mathrm{e}-17$ & -21.74455 & $-21.46972 *$ & -21.65345 \\
1 & 398.8895 & $70.27624^{*}$ & $8.64 \mathrm{e}-18^{*}$ & $-22.30560^{*}$ & -20.38182 & $-21.66792^{*}$ \\
2 & 434.7901 & 42.63195 & $1.12 \mathrm{e}-17$ & -22.29938 & -18.72665 & -21.11512 \\
\hline
\end{tabular}

*indicates lag order selected by the criterion

LR: sequential modified LR test statistic (each test at $5 \%$ level)

FPE: Final prediction error

AIC: Akaike information criterion

SC: Schwarz information criterion

HQ: Hannan-Quinn information criterion 
Tabel 3. Hasil Uji Kausalitas Granger

\begin{tabular}{|c|c|c|c|c|c|}
\hline Null Hypothesis & Obs & F-Statistic & Prob. & Hasil & Hubungan Kausalitas \\
\hline LEDUC does not Granger Cause LCPI & 30 & 2.46312 & 0.0700 & $\begin{array}{l}\text { Tolak Ho } \\
\text { Tolak Ho }\end{array}$ & $\begin{array}{l}\text { Hubungan dua arah } \\
\text { antara pengeluaran } \\
\text { bidano pendidikan dan }\end{array}$ \\
\hline LCPI does not Granger Cause LEDUC & & 4.48636 & 0.0072 & & Inflasi \\
\hline LGDP_PERCAPITA does not Granger Cause LCPI & 30 & 2.12341 & 0.1068 & \multirow{2}{*}{$\begin{array}{l}\text { Terima Ho } \\
\text { Tolak Ho }\end{array}$} & \multirow{2}{*}{$\begin{array}{l}\text { Hubungan satu arah } \\
\text { antara inflasi dengan } \\
\text { PDB per kapita }\end{array}$} \\
\hline LCPI does not Granger Cause LGDP_PERCAPITA & & 2.24161 & 0.0921 & & \\
\hline LGDP_PERCAPITA does not Granger Cause LEDUC & 30 & 2.45113 & 0.0710 & \multirow[t]{2}{*}{$\begin{array}{l}\text { Tolak Ho } \\
\text { Tolak Ho }\end{array}$} & \multirow{2}{*}{$\begin{array}{l}\text { Hubungan dua arah } \\
\text { antara PDB per kapita } \\
\text { dengan pengeluaran } \\
\text { bidang pendidikan }\end{array}$} \\
\hline LEDUC does not Granger Cause LGDP_PERCAPITA & & 2.55573 & 0.0625 & & \\
\hline LTERSIER does not Granger Cause LPRIMER & 30 & 1.75850 & 0.1698 & $\begin{array}{l}\text { Terima Ho } \\
\text { Tolak Ho }\end{array}$ & $\begin{array}{l}\text { Hubungan satu arah } \\
\text { antara partisipasi } \\
\text { sekolah primer dengan } \\
\text { partisipasi sekolah } \\
\text { sekunder }\end{array}$ \\
\hline LTERSIER does not Granger Cause LSEKUNDER & 30 & 0.80146 & 0.5624 & \multirow[t]{2}{*}{$\begin{array}{l}\text { Terima Ho } \\
\text { Tolak Ho }\end{array}$} & \multirow[t]{2}{*}{$\begin{array}{l}\text { Hubungan satu arah } \\
\text { antara partisipasi } \\
\text { sekolah sekunder } \\
\text { dengan sekolah tersier }\end{array}$} \\
\hline & & 4.18920 & 0.0098 & & \\
\hline
\end{tabular}

0,05 , serta dengan melihat nilai probabilitas untuk menunjukkan ada tidaknya persamaan di dalam sistem yang terkointegrasi.

Hasil uji kointegrasi pada Tabel 4 menunjukkan nilai dari trace statistic dari uji trace sebesar 76,31252 lebih besar dari nilai kritis pada alpha 0,05 sebesar 60,06141, artinya di dalam sistem ada dua persamaan yang terkointegrasi. Kemudian dari uji Maximum Eigenvalue, nilai dari trace statistic sebesar 36,34021 yang lebih besar dari nilai kritis 0,05 sebesar 30,43961, artinya terdapat dua persamaan yang terintegrasi.

\section{Uji Signifikansi Hasil Estimasi VECM}

Uji signifikansi variabel dilakukan dengan cara membandingkan nilai statistik t hitung dari hasil estimasi ECM dengan nilai $t$ tabel pada level signifikansi 5 persen sebesar 2,063899. Hasil estimasi VECM (Lampiran 1) yang digaris tebal memperlihatkan berpengaruh secara signifikan. Pengeluaran pemerintah di bidang pendidikan dalam jangka panjang pada kointegrasi yang kedua berpengaruh negatif signifikan terhadap PDB per kapita. Sementara itu, dalam jangka pendek pengeluaran pemerintah di bidang pendidikan tidak memiliki pengaruh signifikan terhadap PDB per kapita Analisis Impulse Response Function (IRF)
Grafik IRF (Lampiran 2) dari masing-masing variabel sebagai response. Analisis IRF diperlukan untuk mengetahui bagaimana pengaruh shock suatu variabel terhadap variabel itu sendiri dan variabel lainnya yang terdapat dalam sistem. IRF menggambarkan bagaimana perkiraan dampak dari shock suatu variabel terhadap variabel-variabel yang lain sehingga bisa diketahui berapa lama pengaruh shock suatu variabel terhadap variabelvariabel yang lain dan variabel manakah yang akan memberi response terbesar terhadap adanya shock.

Analisis IRF dengan PDB per kapita sebagai response menyimpulkan bahwa dalam 10 tahun mendatang, response tertinggi adalah response PDB per kapita terhadap PDB per kapita itu sendiri. Response PDB per kapita terhadap pengeluaran pemerintah di bidang pendidikan akan stabil pada tahun ketujuh dan response-nya cukup kecil dengan angka mendekati nol. Artinya jika terjadi guncangan 1 standar deviasi dari tingkat PDB per kapita, maka akan bereaksi positif namun dengan ukuran yang kecil terhadap pengeluaran pemerintah pada bidang pendidikan.

Analisis IRF dengan pengeluaran pemerintah di bidang pendidikan sebagai response menyimpulkan bahwa di dalam 10 tahun mendatang, response tertinggi adalah response pengeluaran pemerintah di bidang pendidikan terhadap pengeluaran pemerintah di bidang 
Tabel 4. Hasil Uji Johansen Cointegration Test

Unrestricted Cointegration Rank Test (Trace)

\begin{tabular}{|c|c|c|c|c|}
\hline $\begin{array}{l}\text { Hypothesized } \\
\text { No. of CE(s) }\end{array}$ & Eigenvalue & $\begin{array}{c}\text { Trace } \\
\text { Statistic }\end{array}$ & $\begin{array}{c}0.05 \\
\text { Critical Value }\end{array}$ & Prob.** \\
\hline None* & 0.941109 & 164.1066 & 83.93712 & 0.0000 \\
\hline At most $1 *$ & 0.690335 & 76.31252 & 60.06141 & 0.0012 \\
\hline At most 2 & 0.497245 & 39.97231 & 40.17493 & 0.0524 \\
\hline At most 3 & 0.332929 & 18.65512 & 24.27596 & 0.2170 \\
\hline At most 4 & 0.148782 & 6.104490 & 12.32090 & 0.4234 \\
\hline At most 5 & 0.035197 & 1.110787 & 4.129906 & 0.3398 \\
\hline
\end{tabular}

Trace test indicates 2 cointegrating eqn(s) at the 0.05 level

*denotes rejection of the hypothesis at the 0.05 level

**MacKinnon-Haug-Michelis (1999) p-values

Unrestricted Cointegration Rank Test (Maximum Eigenvalue)

\begin{tabular}{ccccc}
\hline $\begin{array}{c}\text { Hypothesized } \\
\text { No. of CE(s) }\end{array}$ & Eigenvalue & $\begin{array}{c}\text { Max-Eigen } \\
\text { Statistic }\end{array}$ & $\begin{array}{c}\mathbf{0 . 0 5} \\
\text { Critical Value }\end{array}$ & Prob.** \\
\hline None $*$ & 0.941109 & 87.79406 & 36.63019 & 0.0000 \\
At most $1 *$ & 0.690335 & 36.34021 & 30.43961 & 0.0082 \\
At most 2 & 0.497245 & 21.31719 & 24.15921 & 0.1158 \\
At most 3 & 0.332929 & 12.55063 & 17.79730 & 0.2582 \\
At most 4 & 0.148782 & 4.993703 & 11.22480 & 0.4782 \\
At most 5 & 0.035197 & 1.110787 & 4.129906 & 0.3398 \\
\hline
\end{tabular}

Max-eigenvalue test indicates 2 cointegrating eqn(s) at the 0.05 level

*denotes rejection of the hypothesis at the 0.05 level

**MacKinnon-Haug-Michelis (1999) p-values

pendidikan itu sendiri, yang diperkirakan akan stabil pada standar deviasi 0,08. Response pengeluaran pemerintah di bidang pendidikan terhadap PDB per kapita menunjukkan response yang negatif dan selalu berfluktuatif sepanjang tahun. Ini artinya jika terjadi guncangan sebesar 1 standar deviasi dari PDB per kapita maka tingkat pengeluaran pemerintah di bidang pendidikan akan bereaksi negatif terhadap PDB per kapita. Hal ini mengindikasikan bahwa apabila pemerintah melanjutkan skema kebijakan pengeluaran pemerintah di bidang pendidikan sama seperti saat ini, maka justru akan memberikan pengaruh yang negatif terhadap PDB per kapita dalam 10 tahun yang akan datang.

\section{Variance Decomposition}

Variance Decomposition dari variabel PDB per kapita pada Tabel 5 menunjukkan bahwa variabel yang diperkirakan akan memiliki kontribusi paling besar terhadap PDB per kapita selain PDB per kapita itu sendiri adalah inflasi dengan rata-rata kontribusi per tahun sebesar 11,54 persen, kemudian diikuti oleh kontribusi tingkat partisipasi pendidikan tersier sebesar 7,42 persen, partisipasi pendidikan sekunder sebesar 7 persen, pengeluaran pemerintah di bidang pendidikan sebesar 5,22 persen, dan partisipasi pendidikan primer sebesar 0,65 persen.

\section{Pembahasan}

Berdasarkan hasil empiris dengan menggunakan model signifikansi VECM ditemukan bahwa pengeluaran pemerintah di bidang pendidikan dalam jangka panjang pada kointegrasi yang kedua berpengaruh negatif signifikan terhadap PDB per kapita. Sementara itu, dalam jangka pendek pengeluaran pemerintah di bidang pendidikan tidak memiliki pengaruh signifikan terhadap PDB per kapita (Tabel 5). Namun demikian, analisis utama VAR maupun VECM terletak pada informasi IRF dan VD yang terdapat dalam permodelan. Lebih jauh, dua output ini merupakan keunggulan model analisis VAR maupun VECM, dibandingkan dengan membaca hasil koefisien model dengan memperhatikan lag karena model VAR maupun VECM memang cukup sulit diinterpretasikan (Batubara \& Saskara, 2015).

Selanjutnya, IRF menunjukkan temuan yang unik dimana response pengeluaran pemerintah di bidang pendidikan terhadap PDB per kapita menunjukkan response yang negatif dan berfluktuatif sepanjang tahun (Lampiran 2). Lebih jauh, ini mengindikasikan bahwa apabila pemerintah masih melanjutkan skema kebijakan 
Tabel 5. Variance Decomposition

\begin{tabular}{cccccccc}
\hline Period & S.E. & D(LGDP) & D(LCPI) & D(LEDUC) & D(LPRIMER) & D(LSEKUNDER) & D(LTERSIER) \\
\hline 1 & 0.033484 & 100 & 0 & 0 & 0 & 0 & 0 \\
2 & 0.043704 & 76.03517 & 13.57901 & 7.909406 & 0.032638 & 0.948827 & 1.494948 \\
3 & 0.050204 & 63.9695 & 15.96724 & 6.021477 & 0.232567 & 3.514642 & 10.29458 \\
4 & 0.054899 & 65.55934 & 13.37859 & 5.166881 & 0.236701 & 6.004533 & 9.653949 \\
5 & 0.058218 & 65.45604 & 12.49169 & 5.939585 & 1.127281 & 6.257684 & 8.727724 \\
6 & 0.061098 & 65.58791 & 12.57295 & 5.816034 & 1.094114 & 6.128017 & 8.80098 \\
7 & 0.06498 & 66.65034 & 12.03922 & 5.401037 & 0.967465 & 6.158603 & 8.783339 \\
8 & 0.068423 & 66.41668 & 11.981 & 5.437611 & 0.949539 & 6.509683 & 8.705494 \\
9 & 0.071207 & 66.14363 & 11.87071 & 5.343634 & 0.931154 & 6.791436 & 8.919434 \\
10 & 0.074043 & 66.60029 & 11.48789 & 5.197299 & 0.905121 & 6.968934 & 8.840458 \\
Rata-rata & $\mathbf{0 . 0 5 8 0 2 6}$ & $\mathbf{7 0 . 2 4 1 8 9}$ & $\mathbf{1 1 . 5 3 6 8 3}$ & $\mathbf{5 . 2 2 3 2 9 6}$ & $\mathbf{0 . 6 4 7 6 5 8}$ & $\mathbf{4 . 9 2 8 2 3 6}$ & $\mathbf{7 . 4 2 2 0 9 1}$ \\
\hline
\end{tabular}

pengeluaran pemerintah di bidang pendidikan yang sama, maka secara empiris akan berpengaruh negatif terhadap PDB per kapita dalam 10 tahun yang akan datang. Temuan ini juga sejalan dengan VD yang menunjukkan secara empiris bahwa pengeluaran pemerintah di bidang pendidikan hanya berkontribusi rata-rata 5,2 persen dalam 10 tahun (Tabel 5). Variabel lain yang lebih kuat berkontribusi terhadap PDB per kapita masingmasing secara berurutan adalah PDB per kapita itu sendiri, inflasi, tingkat partisipasi pendidikan tersier, sekunder, dan primer. Dengan demikian, dapat disimpulkan bahwa pengeluaran pemerintah di bidang pendidikan berpengaruh terhadap PDB per kapita namun dengan kontribusi yang belum optimal.

Saraswati (2013) menjelaskan bahwa belum optimalnya peran pengeluaran pemerintah di bidang pendidikan terhadap PDB per kapita disebabkan oleh tiga faktor, yaitu distribusi populasi, etnis yang beragam, dan struktur sosial. Ini juga didukung oleh fakta bahwa Indonesia memiliki karakteristik unik secara budaya, regional, dan geografis. Meskipun demikian, pemerintah terus berupaya untuk meningkatkan pengeluaran di bidang pendidikan demi menghasilkan lebih banyak SDM berpendidikan dan terampil yang dapat berkontribusi terhadap peningkatan pendapatan dan pertumbuhan ekonomi yang lebih baik.

Selanjutnya, terkait dengan dampak yang pengeluaran pemerintah yang belum optimal terhadap PDB per kapita bisa dijelaksan melalui mekanisme transmisi outcome pembelajaran. Jasmina (2017) menemukan bahwa pengeluaran pemerintah pusat maupun daerah di bidang pendidikan tidak berpengaruh signifikan terhadap outcome pembelajaran, yang dalam hal ini diproksikan oleh hasil belajar siswa. Lebih lanjut, temuan ini mengindikasikan bahwa bukan hanya seberapa besar atau ukuran pengeluaran pemerintah di bidang pendidikan, tetapi juga bagaimana pemerintah dapat menggunakan pengeluaran tersebut secara efektif.
Sejalan dengan argumentasi sebelumnya, Wika \& Widodo (2012) mengungkapkan bahwa pengeluaran pemerintah di bidang pendidikan kurang progresif dan cenderung memberi manfaat lebih untuk kelompok ekonomi kelas menengah dan kaya. Meskipun demikian, apabila didisagregasi pada level pendidikan menunjukkan bahwa pendidikan dasar sangat pro terhadap masyarakat ekonomi kelas miskin. Sementara itu, pada level pendidikan menengah dan tinggi lebih pro terhadap kelompok masyarakan ekonomi kelas kaya.

Secara umum, temuan dari berbagai penelitian sebelumnya terkait belum optimalnya anggaran pengeluaran pemerintah di bidang pendidikan terhadap PDB per kapita sejalan dengan kondisi saat ini. Faktanya, berdasarkan Grafik 3 menunjukkan bahwa pengeluaran pemerintah di bidang pendidikan selalu meningkat selama periode

\section{Grafik 3. Anggaran Pendidikan Indonesia 2010-2020 (triliun Rp)}

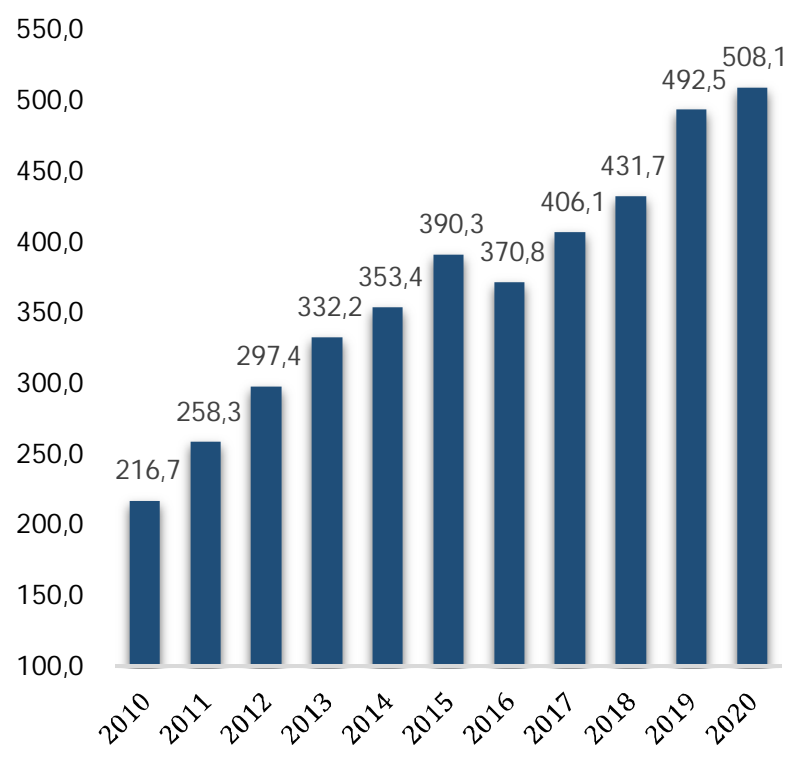

Sumber: Kementerian Keuangan (2021), diolah 
2010-2020. Hanya pada tahun 2016 saja mengalami penurunan, namun kemudian kembali meningkat sampai Rp508,1 triliun pada tahun 2020.

Namun demikian, Grafik 4 menunjukkan bahwa pengeluaran pemerintah di bidang pendidikan apabila didisagregasi pada level provinsi maka akan terlihat jelas bahwa terjadi disparitas yang sangat tinggi, terutama antara wilayah Jawa dengan yang lain. Hal ini yang kemudian menjadi tantangan pemerintah dalam menyusun dan mengimplementasikan kebijakan pengeluaran pemerintah di bidang pendidikan yang setara. Dalam hal ini, apabila ingin melihat dampak holistik terhadap pembangunan SDM secara nasional, maka dimulai dari perencanaan yang baik dan berkeadilan. Dengan demikian, transmisi kebijakan di bidang pendidikan terhadap PDB per kapita akan lebih merata dan berdampak nyata terhadap kesejahteraan individu secara khusus dan perekonomian nasional secara umum.
Bagaimanapun juga, pemerintah telah berusaha dengan berbagai upaya untuk terus menjaga bahkan meningkatkan pengeluaran pemerintah di bidang pendidikan dalam rangka mengandalkan investasi pada SDM. Peran ini masih terus dijaga dan diimplementasikan melalui pengeluaran pemerintah di bidang pendidikan yang berkesinambungan. Lebih dari itu, tantangan terbesar bidang pendidikan di Indonesia adalah pemerataan. Untuk mencapai sasaran PDB per kapita yang lebih setara dan perekonomian yang berkelanjutan perlu melibatkan berbagai macam pihak dari level pusat sampai tingkat daerah. Dengan demikian, "Spending More" di bidang pendidikan untuk meningkat ouput pendidikan yang berdampak pada produktivitas dan mendorong kesejahteraan bukan menjadi cara yang terbaik.

World Bank (2013) mengajukan sebuah konsep "Spending Better" yang diartikan sebagai pengeluaran yang memastikan sumber daya

\section{Grafik 4. Realisasi Belanja Pendidikan pada APBD 2018 (triliun Rp)}

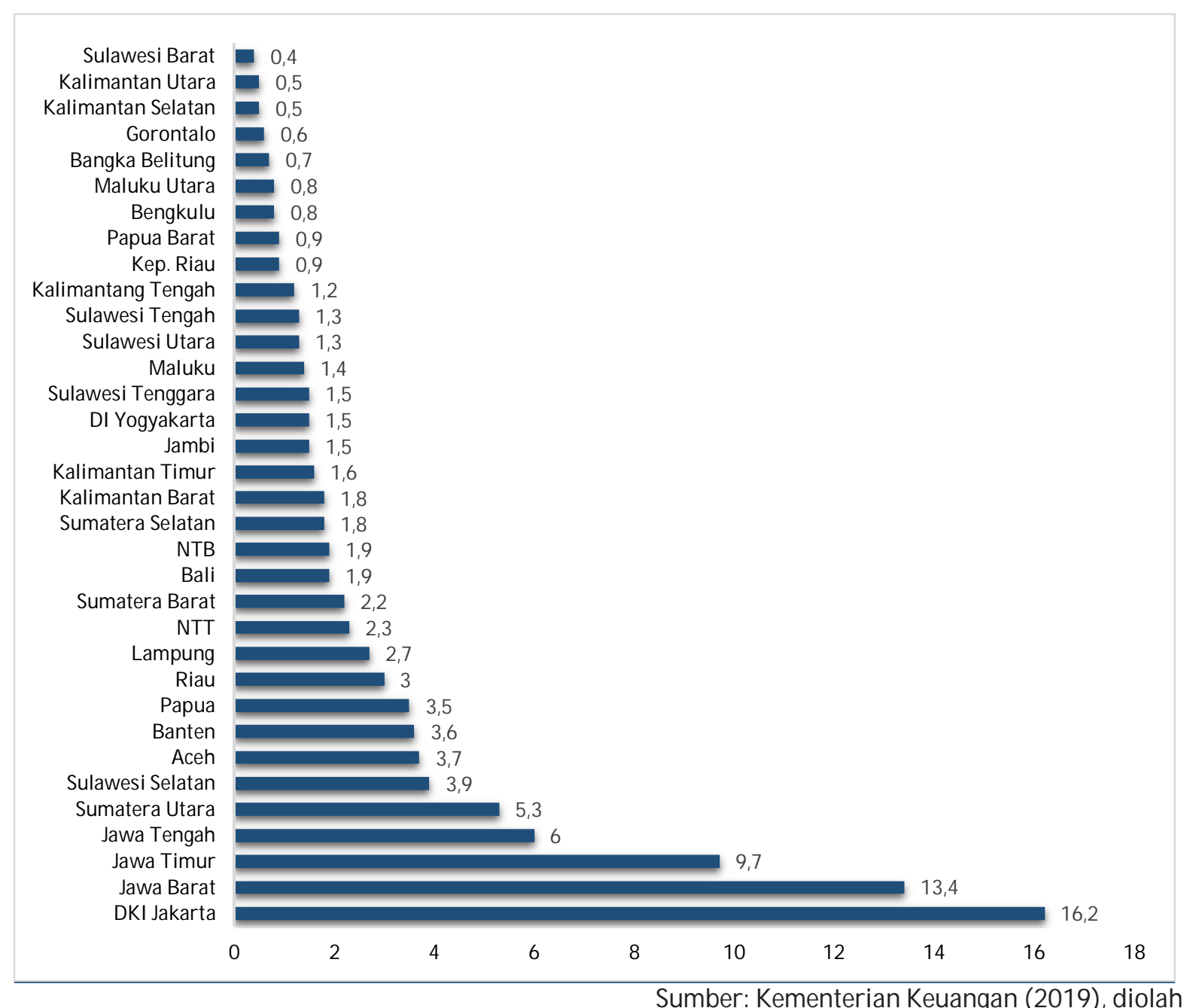


dialokasikan secara lebih efektif untuk menghasilkan hasil yang lebih baik sehubungan dengan akses dan pembelajaran. Mengingat kompleksitas tata kelola sistem pendidikan di Indonesia, sehingga hal ini menjadi tugas yang sulit, dan tugas tersebut harus berfokus pada kapasitas kabupaten untuk mengelola sistem. Kabupaten mengelola sekolah dan guru yang merupakan dua input utama dalam proses pembelajaran. Tetapi karena kabupaten bergantung pada transfer pemerintah pusat untuk besar anggaran kabupaten, besaran belanja pendidikan juga dipengaruhi oleh insentif yang menentukan jumlah sebagaimana dalam formula transfer.

Selanjutnya, melihat struktur insentif tersebut maka lebih jauh dapat dijelaskan mengapa kabupaten menghabiskan sebagian besar pada salah satu dari input yaitu guru, sementara dukungan mereka untuk sekolah masih sangat terbatas. Meningkatkan pengeluaran dalam pendidikan dasar akan berarti mencapai pengeluaran yang lebih seimbang di tingkat kabupaten dan memastikan bahwa insentif sejalan dengan tujuan meningkatkan kualitas pendidikan.

\section{KESIMPULAN}

Pengeluaran pemerintah di bidang pendidikan menunjukkan tren yang baik. Hal ini ditunjukkan melalui alokasi anggaran yang selalu meningkat dalam beberapa tahun terakhir. Lebih jauh, ini menunjukkan komitmen pemerintah Indonesia dalam melakukan investasi melaui SDM. Karena, SDM yang berpendidikan dan terampil akan menciptakan tenaga kerja yang kompetitif dan berdaya saing di pasar tenaga kerja. Pada gilirannya, pasar tenaga kerja yang diisi oleh tenaga kerja yang memiliki daya saing dan terampil berdampak pada peningkatan produktivitas yang mendorong perekonomian nasional dan pada akhirnya meningkatkan kesejahteraan.

Hasil uji empiris menunjukkan bahwa pengeluaran pemerintah di bidang pendidikan terhadap PDB per kapita belum berdampak secara optimal. Disparitas pengeluaran pemerintah antar wilayah di Indonesia menjadi salah satu penyebab utamanya. Selain itu, sistem pendidikan Indonesia yang kompleks serta kondisi geografis, sosial, budaya, dan populasi yang beragam mengakibatkan distorsi transmisi kebijakan pengeluaran pemerintah di bidang pendidikan terhadap tujuan yang ingin dicapai. Untuk mengatasi hal tersebut, diperlukan kerja sama erat dan kuat antar pemangku kebijakan dari level pusat sampai daerah dalam mewujudkan pengeluaran pemerintah di bidang pendidikan dengan berorientasi hasil yang lebih baik.

\section{IMPLIKASI DAN KETERBATASAN}

Penelitian ini memiliki implikasi yang kuat terhadap isu kapasitas dan kesinambungan fiskal. Kebijakan yang baik akan berjalan apabila didukung oleh anggaran yang memadai. Salah satu kebijakan yang selalu menjadi prioritas adalah di bidang pendidikan. Secara umum, tujuan dari pendidikan akan berjalan dengan baik seiring dengan komitmen pemerintah dalam mengalokasikan anggaran belanja di bidang pendidikan secara berkelanjutan. Lebih jauh, anggaran tersebut akan berperan sangat penting dalam mencapai tujuan pendidikan melalui penyediaan fasilitas pendidikan dan insentif bagi para pengajar.

Selanjutnya, yang perlu menjadi fokus adalah melakukan pendekatan secara kedaerahan dalam penyelenggaraan pendidikan termasuk di dalamnya terkait isu kebutuhan anggaran di bidang pendidikan. Sistem pendidikan Indonesia yang komplek serta kondisi geografi, sosial, dan budaya yang beragam menuntut kreativitas dan efektivitas dari hulu sampai ke hilir. Pada akhirnya, apa yang menjadi fokus pemerintah adalah memastikan pengeluaran yang telah dilakukan bisa mencapai output yang diharapkan. Oleh karena itu, sinergi kebijakan dari level pusat sampai daerah menjadi sebuah keharusan.

Bagaimanapun juga, penelitian ini sangat terbatas pada proksi variabel makro secara agregat. Namun demikian, diharapkan melalui penelitian ini akan didapatkan gambaran besar kondisi pendidikan sebagai salah satu kewajiban pemerintah dalam menyediakan kebutuhan dasar publik. Penelitian yang akan datang didorong untuk lebih mengeksplorasi pada level mikro sehingga akan terlihat perilaku individu dan isu pendidikan di tingkat daerah. Selain itu, pemilihan proxy variabel yang lebih mendekati kondisi nyata juga diharapkan akan menghasilkan temuan yang lebih baik sehingga akan memicu dan memacu penyusunan kerangka besar kebijakan publik terutama di bidang pendidikan.

\section{DAFTAR PUSTAKA}

Al-samarrai, S., Cerdan-infantes, P., \& Lehe, J. (2019). Mobilizing Resources for Education and Improving Spending Effectiveness Establishing Realistic Benchmarks Based on Past Trends. World Bank Policy Research Working Paper, (8773).

Amaghionyeodiwe, L. A. (2015). Government Spending on Education and Economic Growth: A Case Study of West African Countries. working paper, City University of New York, Jamaica, NY

Appiah, E. N. (2017). The Effect of Education 
Expenditure on Per Capita GDP in Developing Countries. International Journal of Economic Finance., 9(10), 136-144. https:// doi.org/ 10.5539/ ijef.v9n10p136

Badan Pusat Statistik. (2019). Produk Domestik Regional Bruto Per Kapita (Ribu Rupiah). Diunduh di https:// bps.go.id/indicator/ 52/ 288/ 1/-seri-2010-produk-domestik-regional -bruto-per-kapita.html

Badan Pusat Statistik. (2020). Distribusi PDRB Terhadap Jumlah PDRB 34 Provinsi Atas Dasar Harga Berlaku Menurut Provinsi (Persen). Diunduh di https:/ / bps.go.id/ indicator/ 52/ 289/ 1/ -seri2010-distribusi-pdrb-terhadap-jumlah-pdrb34-provinsi-atas-dasar-harga-berlakumenurut-provinsi.html

Batubara, D. M. H., \& Saskara, I. A. N. (2015). Analisis Hubungan Ekspor, Impor, PDB, Causality And Co-Integration Analysis Between Exports, Imports. Jurnal Ekonomi Kuantitatif Terapan. 8(1), 46-55.

Castro-Leal, F., Dayton, J., Demery, L., \& Mehra, K. (2000). Public spending on health care in Africa: Do the poor benefit? Bulletin World Health Organitation. 78, 66-74. https:// doi.org/ 10.1590/ S00429686200007

Cobb, C. W., \& Douglas, P. H. (1928). A Theory of Production Competence. American Economic Review 18, 139-165. https:// doi.org/ 10.1111/j.1540-5915.1989.tb01410.x

Dao, M. Q. (2012). Government expenditure and growth in developing countries. Program Devevelopment Studies. 12(1), 77-82. https:// doi.org/ 10.1177/ 146499341101200105

Dickey, D. A., \& Fuller, W. A. (1979). Distribution of the Estimators for Autoregressive Time Series With a Unit Root. Journal of American Statistic. Association. 74(366a), 427-431. https:// doi.org/ 10.2307/ 2286348

Ekinci, E., Karaçor, Z., Konya, S., \& Güvenek, B. (2017). Relationship With Education Expenditure and Economic Growth in Oecd Countries: a Panel Data Analysis. DIEM Dubrovnik International Economic Meeting. 3(1), 255-269.

Engle, R. F., \& Granger, C. W. J. (1987). CoIntegration and Error Correction: Representation, Estimation,. Econometrica: journal of the Econometric Society, 55, 251276.

Frank, N. (2018). Making the Grade: The Contribution of Education Expenditure to Economic Growth. Undergraduate Economic Review. 14(1), 11.

Granger, C. W. J. (1981). Some properties of time series data and their use in econometric model specification. Journal of Econometrics 16(1), 121-130. https:// doi.org/ 10.1016/ 0304-
4076(81)90079-8

Guisan, M. C. (2006). Direct and Indirect Effects of Human Capital on World. Applied Economic International Development. 6(1), 17-34.

Hall, D. (2014). Why We Need Public Spending. Brussels, Belgium:European Federation of Public Service Unions.

Hawkes, D., \& Ugur, M. (2012). Evidence on the relationship between education, skills and economic growth in low-income countries: A systematic review. Evidence for Policy and Practice Information and Co-ordinating Centre (EPPI-Centre).

Ifa, A., \& Guetat, I. (2018). Does public expenditure on education promote Tunisian and Moroccan GDP per capita? ARDL approach. Journal of Financial Data Science. 4(4), 234-246. https:/ / doi.org/ 10.1016 / j.jfds.2018.02.005

Jasmina, T. (2017). Public Spending and Learning Outcomes of Basic Education at the District Level in Indonesia. Economic Finance Indonesia. $\quad 62(3)$, 180-190. https:/ / doi.org/ 10.7454/ efi.v62i3.556

Johansen, S. (1991). Estimation and Hypothesis Testing of Cointegration Vectors in Gaussian Vector Autoregressive Models. Econometrica: journal of the Econometric Society, 59, 1551$1580 . \quad$ https:// doi.org/ 10.1017/ CBO9781107415324.004

Johansen, S. (1988). Statistical analysis of cointegration vectors. Journal of Economic Dynamic Control 12(2-3), 231-254. https:// doi.org/ 10.1016/ 0165-1889(88)90041-3

Kementerian Keuangan. (2019). Belanja Menurut Fungsi Pada Realisasi APBD 2018. Diunduh di http:/ / www.djpk.kemenkeu.go.id/ wpcontent/ uploads/ 2019/ 09/ Real APBD2018 perfungsi_SIKD_update-5Sept2019-1.xlsx

Kementerian Keuangan. (2021). Laporan Keuangan Pemerintah Pusat. Diunduh di https:/ / www.kemenkeu.go.id/ publikasi/ lapo ran/ laporan-keuangan-pemerintah-pusat/

Kouton, J. (2018). Education expenditure and economic growth: Some empirical evidence from Côte d'Ivoire. Journal of Economics and Sustainable Development. 14(9), 22-34.

Liu, L. C., Hsu, C. E., \& Younis, M. Z., (2008). The association between government expenditure and economic growth: granger causality test of US data, 1947-2002. Journal of Public Budgeting, Accounting \& Financial Management. 20(4), 439-452.

MacKinnon, J. G., Haug, A. A., \& Michelis, L. (1999). Numerical distribution functions of likelihood ratio tests for cointegration. Journal of applied Econometrics, 14(5), 563-577.

Maitra, B., \& Mukhopadhyay, C. K. (2012). Public spending on education, health care and economic growth in selected countries of Asia 
and the Pacific. Asia-Pacific Development Journal. 19(2), 19-48. https:// doi.org/ 10.18356/ e7c7bcb7-en

Nose, M. (2015). Estimation of drivers of public education expenditure: Baumol's effect revisited. International Tax and Public Finance, 24(3), 512-535.

OECD/ ADB. (2015). Education in Indonesia: Rising to the Challenge. Paris, France: OECD Publishing. https:// doi.org/ 10.1525 / as.1951.20.15.01p0699q

OECD. (2006). The Returns to Education: Links Between Education, Economic Growth, and Social Outcomes in: Education at a Glance. Paris, France: OECD Publishing. https:/ / doi.org/ 10.1787/ eag-2006-11-en.

Ozawa, M., \& Lee, Y.S. (2011). Generational inequity in social spending: The United States in comparative perspective. International Social Work 56(2), 162-179. https:// doi.org/ $10.1177 / 0020872811417475$

Saraswati, E. (2013). Public Spending Education and Inequality: A Case Study in Indonesia. International Journal of Social Science Humanity. 2(5), 427-431. https:// doi.org/ 10.7763/ ijssh.2012.v2.139

Shafuda, C. P. P., \& De, U. K. (2020). Government expenditure on human capital and growth in Namibia: a time series analysis. Journal of Economic Structure. 9(1), 1-14. https:/ / doi.org/ 10.1186/ s40008-020001963

Sims, C. A. (1980). Macroeconomics and Reality. Economic Society. Econometrica: journal of the Econometric Society. 48, 1-48. https:/ / doi.org/ 10.1017/ CBO978110741532 4.004

Taruno, H. T. (2019). Public Spending and Poverty Reduction in Indonesia: The Effects of Economic Growth and Public Spending on Poverty Reduction in Indonesia 2009-2018. The Indonesian Journal of Planning and Development, 4(2), 49-56. https:// doi.org/ 10.14710/ ijpd.4.2.49-56

Wika, G. S. M. J., \& Widodo, T. (2012). Distribution of government spending on education in Indonesia. MPRA Paper 79501.

World Bank. (2013). Spending more or spending better: Improving education financing in Indonesia.Jakarta,Indonesia: World Bank. 


\begin{tabular}{ccc}
\hline \multicolumn{3}{c}{ Lampiran 1. Hasil Estimasi VECM } \\
\multicolumn{3}{c}{ Jangka Panjang } \\
\hline Cointegrating Eq: & CointEq1 & CointEq2 \\
\hline D(LGDP(-1)) & 1.000000 & 0.000000 \\
D(LCPI(-1)) & 0.000000 & 1.000000 \\
D(LEDUC(-1)) & 0.049793 & $\mathbf{- 0 . 5 9 2 2 3 4}$ \\
& {$[0.06922)$} & $\mathbf{( 0 . 1 8 4 3 0 )}$ \\
& {$[0.71935]$} & {$[-\mathbf{3 . 2 1 3 5 0 ]}$} \\
D(LPRIMER(-1)) & $\mathbf{- 4 . 2 5 2 3 2 6}$ & $\mathbf{2 0 . 0 9 1 7 6}$ \\
& $\mathbf{( 1 . 3 1 6 9 9 )}$ & $\mathbf{( 3 . 5 0 6 4 5 )}$ \\
& {$[-3.22883]$} & {$[\mathbf{5 . 7 2 9 9 5 ]}$} \\
D(LSEKUNDER(-1)) & $\mathbf{0 . 8 8 1 2 7 4}$ & $\mathbf{- 2 . 1 4 3 7 3 1}$ \\
& $\mathbf{( 0 . 2 8 1 5 1 )}$ & $\mathbf{( 0 . 7 4 9 5 1 )}$ \\
& {$[\mathbf{3 . 1 3 0 5 3 ]}$} & {$[-\mathbf{2 . 8 6 0 1 6}]$} \\
& $\mathbf{- 1 . 3 3 8 7 8 7}$ & $\mathbf{1 . 9 2 1 0 1 3}$ \\
D(LTERSIER(-1)) & $\mathbf{( 0 . 2 2 7 8 1 )}$ & $\mathbf{( 0 . 6 0 6 5 4 )}$ \\
& {$[-\mathbf{5 . 8 7 6 7 5 ]}$} & {$[\mathbf{3 . 1 6 7 1 6}]$} \\
\hline
\end{tabular}

Jangka Pendek

\begin{tabular}{|c|c|c|c|c|c|c|}
\hline Error Correction: & D(LGDP,2) & D(LCPI,2) & D(LEDUC,2) & D(LPRIMER,2) & D(LSEKUNDER,2) & D(LTERSIER,2) \\
\hline CointEq1 & $\begin{array}{c}-0.589265 \\
(0.28768) \\
{[-2.04835]}\end{array}$ & $\begin{array}{c}0.618574 \\
(0.64546) \\
{[0.95834]}\end{array}$ & $\begin{array}{c}-0.479452 \\
(0.92097) \\
{[-0.52059]}\end{array}$ & $\begin{array}{c}-0.032497 \\
(0.08643) \\
{[-0.37599]}\end{array}$ & $\begin{array}{c}-0.146172 \\
(0.37616) \\
{[-0.38859]}\end{array}$ & $\begin{array}{c}2.310256 \\
(0.43576) \\
{[5.30162]}\end{array}$ \\
\hline CointEq2 & $\begin{array}{c}-0.166513 \\
(0.11283) \\
{[-1.47574]}\end{array}$ & $\begin{array}{c}0.122629 \\
(0.25316) \\
{[0.48438]}\end{array}$ & $\begin{array}{c}0.075755 \\
(0.36122) \\
{[0.20972]}\end{array}$ & $\begin{array}{c}-0.055544 \\
(0.03390) \\
{[-1.63849]}\end{array}$ & $\begin{array}{c}-0.054449 \\
(0.14754) \\
{[-0.36905]}\end{array}$ & $\begin{array}{c}0.773125 \\
(0.17092) \\
{[4.52343]}\end{array}$ \\
\hline $\mathrm{D}(\operatorname{LGDP}(-1), 2)$ & $\begin{array}{c}0.956546 \\
(0.51113) \\
{[1.87143]}\end{array}$ & $\begin{array}{l}-1.709178 \\
(1.14683) \\
{[-1.49035]}\end{array}$ & $\begin{array}{l}2.563679 \\
(1.63634) \\
{[1.56672]}\end{array}$ & $\begin{array}{c}-0.222614 \\
(0.15356) \\
{[-1.44964]}\end{array}$ & $\begin{array}{c}1.040485 \\
(0.66834) \\
{[1.55683]}\end{array}$ & $\begin{array}{c}-1.256546 \\
(0.77424) \\
{[-1.62294]}\end{array}$ \\
\hline D(LCPI $(-1), 2)$ & $\begin{array}{c}0.625655 \\
(0.23890) \\
{[2.61890]}\end{array}$ & $\begin{array}{c}-1.143018 \\
(0.53602) \\
{[-2.13242]}\end{array}$ & $\begin{array}{l}2.085558 \\
(0.76481) \\
{[2.72689]}\end{array}$ & $\begin{array}{c}-0.012637 \\
(0.07178) \\
{[-0.17606]}\end{array}$ & $\begin{array}{c}0.517079 \\
(0.31238) \\
{[1.65531]}\end{array}$ & $\begin{array}{c}-0.573901 \\
(0.36188) \\
{[-1.58590]}\end{array}$ \\
\hline D(LEDUC(-1),2) & $\begin{array}{c}0.071234 \\
(0.04209) \\
{[1.69246]}\end{array}$ & $\begin{array}{c}-0.228439 \\
(0.09444) \\
{[-2.41901]}\end{array}$ & $\begin{array}{c}-0.080325 \\
(0.13474) \\
{[-0.59613]}\end{array}$ & $\begin{array}{c}-0.000133 \\
(0.01265) \\
{[-0.01055]}\end{array}$ & $\begin{array}{c}0.004504 \\
(0.05503) \\
{[0.08185]}\end{array}$ & $\begin{array}{c}\mathbf{0 . 1 6 9 7 8 4} \\
(\mathbf{0 . 0 6 3 7 5 )} \\
{[2.66308]}\end{array}$ \\
\hline D(LPRIMER(-1),2) & $\begin{array}{c}1.199428 \\
(0.86099) \\
{[1.39309]}\end{array}$ & $\begin{array}{l}-0.407547 \\
(1.93180) \\
{[-0.21097]}\end{array}$ & $\begin{array}{c}1.551264 \\
(2.75636) \\
{[0.56279]}\end{array}$ & $\begin{array}{c}-0.242579 \\
(0.25868) \\
{[-0.93777]}\end{array}$ & $\begin{array}{c}-0.483934 \\
(1.12579) \\
{[-0.42986]}\end{array}$ & $\begin{array}{c}-2.680434 \\
(1.30419) \\
{[-2.05525]}\end{array}$ \\
\hline D(LSEKUNDER(-1),2) & $\begin{array}{c}-0.014544 \\
(0.17480) \\
{[-0.08320]}\end{array}$ & $\begin{array}{l}-0.005925 \\
(0.39219) \\
{[-0.01511]}\end{array}$ & $\begin{array}{c}-0.729933 \\
(0.55960) \\
{[-1.30439]}\end{array}$ & $\begin{array}{c}0.004767 \\
(0.05252) \\
{[0.09078]}\end{array}$ & $\begin{array}{c}-0.129639 \\
(0.22856) \\
{[-0.56721]}\end{array}$ & $\begin{array}{c}-0.334421 \\
(0.26478) \\
{[-1.26303]}\end{array}$ \\
\hline D(LTERSIER(-1),2) & $\begin{array}{c}-\mathbf{0 . 3 3 6 6 7 0} \\
\mathbf{( 0 . 1 0 6 1 2 )} \\
{[-3.17247]}\end{array}$ & $\begin{array}{l}0.489613 \\
(0.23811) \\
{[2.05628]}\end{array}$ & $\begin{array}{c}-0.738793 \\
(0.33974) \\
{[-2.17459]}\end{array}$ & $\begin{array}{c}0.011066 \\
(0.03188) \\
{[0.34708]}\end{array}$ & $\begin{array}{l}-0.066147 \\
(0.13876) \\
{[-0.47670]}\end{array}$ & $\begin{array}{c}0.021115 \\
(0.16075) \\
{[0.13136]}\end{array}$ \\
\hline
\end{tabular}




\section{Lampiran 2. Impulse Respone Function}

Response to Cholesky One S.D. (d.f. adjusted) Innovations

Response of $\mathrm{D}(\mathrm{LGDP})$ to Innovations

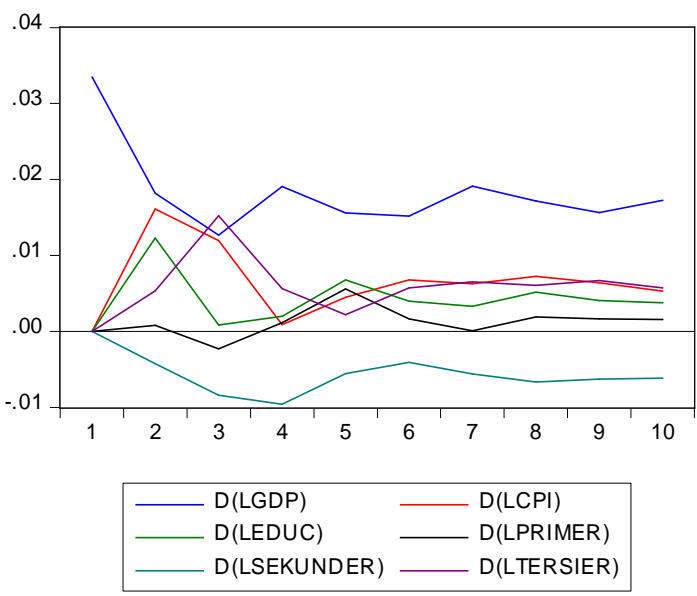

Response of $\mathrm{D}$ (LEDUC) to Innovations

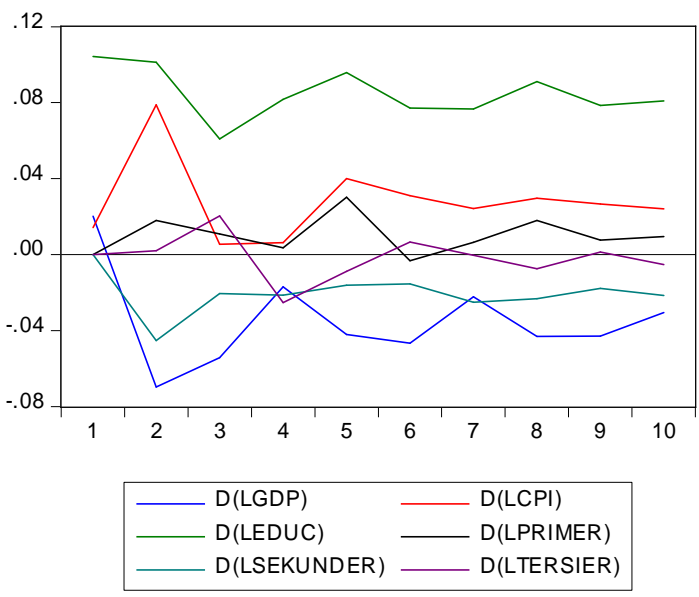

Response of $\mathrm{D}($ LSEKUNDER) to Innovations

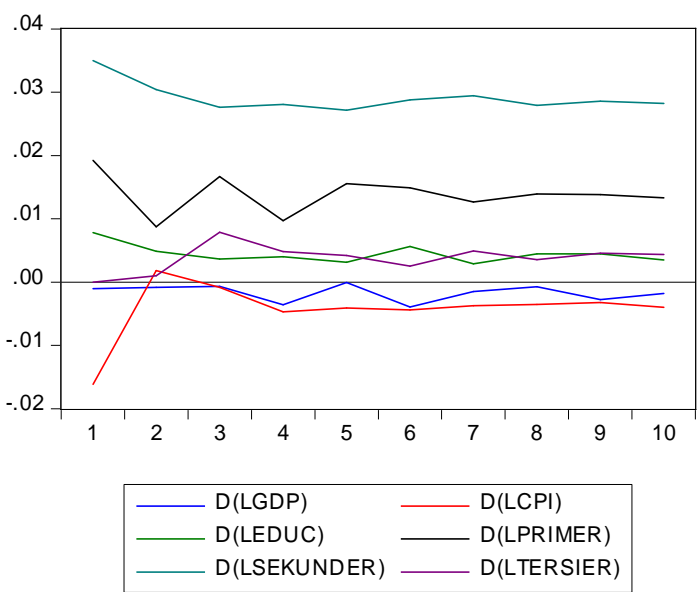

Response of $\mathrm{D}(\mathrm{LCPI})$ to Innovations

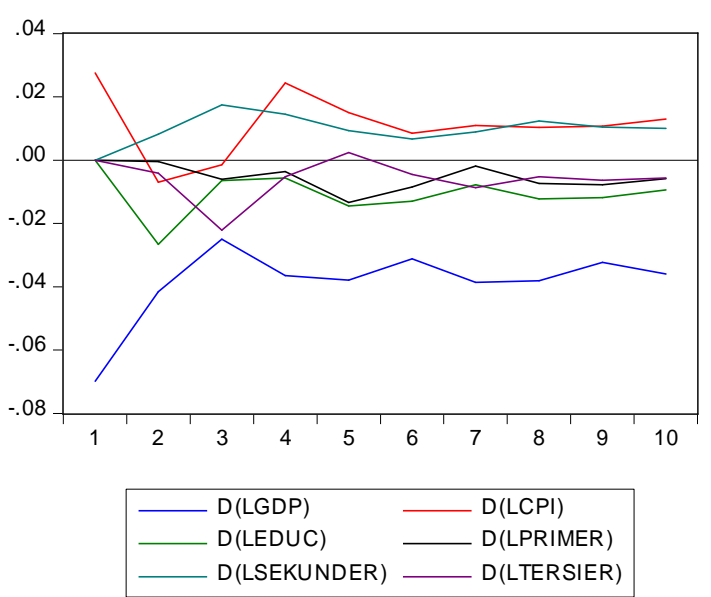

Response of $\mathrm{D}$ (LPRIMER) to Innovations

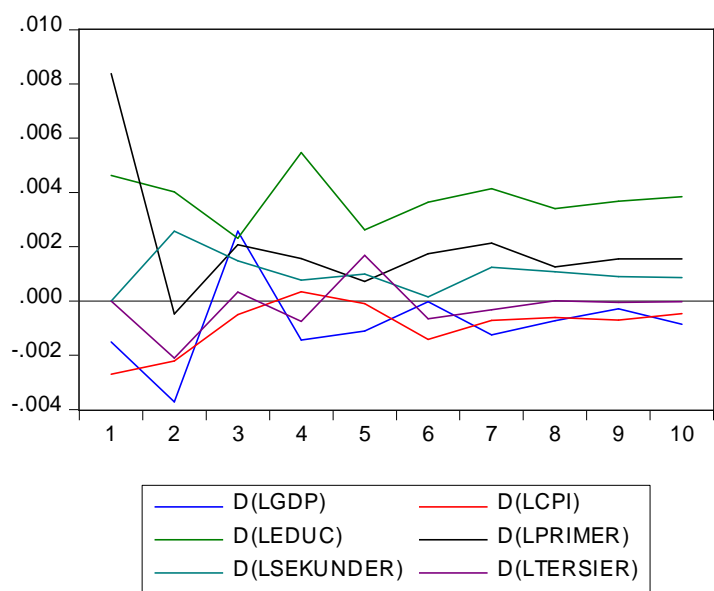

Response of $\mathrm{D}(\mathrm{LTERSIER})$ to Innovations

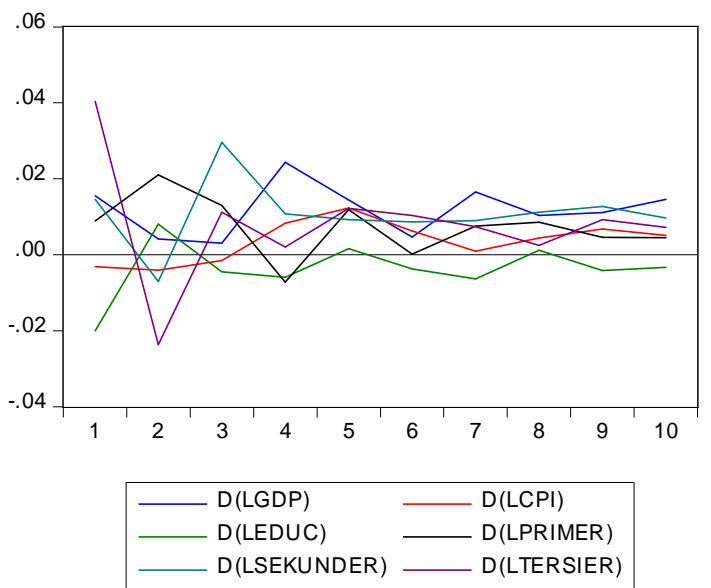

